On being circuited through 3,500 ohms for $23 \mathrm{~min}$, the E.M.F. rose to 1383 .

More observations were made than those here recorded, readings being taken in some cases every minute, but the only irregularity observed was that noticed when working through $30 \mathrm{ohms.}$

In these experiments we may notice that when the battery was short circuited tbrough Io ohms, the E.M.F. after the first two minutes fell $4 \frac{1}{4}$ per cent. in $I^{\frac{1}{2}}$ hours; through $20 \mathrm{ohms}$ it fell 3 per cent. ; and through $30 \mathrm{ohms}, 2 \frac{3}{4}$ per cent., in the same time. But when circuited through $100 \mathrm{ohms}$ and upwards, the E.M.F. increased with the time, ${ }^{*}$ the percentage increment increasing with the resistance. Hence it appears not unlikely that there may be some resistance through which the E.M.F. will remain absolutely constant; should this be found to be the case, and should this resistance always remain the same, the battery will be very valuable when required to work through such a circuit.

It may be remarked that, in accordance with the ustral rule, the E.M.F. of the hattery increases with the external resistance.

The cell was insulated for a considerable time previsusly to commencing each set of experiments.

Cavendish Laboratory, Cambridge

\section{OUR BOTANICAL COLUMN}

Exotic Timber-tries in Mauritius.-Amongst useful plants that have been introduced into countries distant from their native habitats, the timber-trees are of some interest, inasmuch as beyond the proof of their establishment in foreign climates and soils, some time is needed to prove what effects the change may have on the quality of the timber itself, for on this alone depends the value of the experiment in a commercial point of view. It is, however, satisfactory to learn that some wellknown timber-trees that have been introduced into Mauritius throigh the instrumentality of the Royal Gardens, Kew, are in a floutishing state. Thus, the mahogany (Swietenta mahagoni), cne of the oldest and most valued of furoiture woods, has made a very a apid growth, forming, in three or four years after the sowing of the seeds, trees about twenty feet in height, with stems from three to six inches in diameter. In India, likewise, the mahogany thrives well, and as a proof that the wcod is valuable, it may be stated that a tree blown down in the Calcutta Botanic Gardens during the great cyclone realised over $\mathrm{r}, \mathrm{co0}$ rupees. Logwood (Hamatoxylon campeachianum) is reported also to grow well in Mauritius, and it moreover makes excellent hedges, far superior, it is said, to hawthorn. It has been quite naturalised on the hills and waste lands in the vicinity of Port Louis, and annually produces large quantities of seeds.

Bamfoo as a Paper Material.-A good deal of attention has of late years been directed to new materials for paper making. Esparto has been one of the most successful of modern discoveries, and now we are told that the supplies of that useful substance are decreasing and must in course of time fail alto. gether. Where then shall we look for our future supplies is a question that has agitated many minds, and which has been answered frequently by references to the numerous fibre-producing plants of both the East and West Indies, Australia, \&c. We know that in India the fibrous barks of many trees, and notably that of Daphne papyracca, are used for paper making; while in China and Japan, where paper is used for a much greater vaxiety of purposes than it is in England, the barks of Brozssonetia papyrifera and $B$. Kamfferi are made into paper of every conceivable and indeed inconceivable form; for some specimens are so much like leather that it takes a critical eye to detect it, and others are such good imitations of crape and muslin that the same care is needer to de termine their true nature. That the Chinese and Japanese excel in paper-making cannot be doubted, when we consider all their manufactures, and more especially that fine quality of paper known as India proof paper, which they make from young bamboos. The bamboo as a paper material in this country is a comparatively modern introduction; indeed, we can hardly say that it has actually become a commercial article, but there seems no reason why the stems of the bamboo, which in tropical countries is one of the commonest and fastest growing plants, should not be con.

* As the coils were arranged in boxes, and so could not be kept at a uniform temperature, it was thought that this might be due to unequal heating. It was found, however, that the alteration in the ratio of the resistances due to this cause was such as to cause the E.M.F. to appear to increase less than it really did by about 'cos per cent. in one hour, which would not affect the results in the tables. verted into half stuff and sent to England in almost any quantity. To make this material better known has been the aim of Mr. Thos. Routledge, in a little pamphlet of forty pages, which he has just issued. Mr. Routledge is no doubt able to speak with authority on the details of manipulation of paper stock in a practical, if not in a scientific sense; but it is not our intention to follow him through the subject, but simply to refer to some facts quoted by him as an illustration of the suitability of bamboo as a paper-making material, and to endorse to a certain extent some of those facts and suggestions. Thus, with regard to supply, it is well known that in most tropical countries bamboos of various species flourish to a considerable extent and are to the people of immense value, furnishing them with numerous articles of daily necessity ; then again their growth is so rapid as to form a constant supply. With regard to the rate of growth, we read that at Gehzireh, the gardens of the Khedive of Egypt at Cairo, it has been known to grow nine inches in one night. At Sion House, the Duke of Northumberland's, stems of Bambusa gigantea have attained the height of 60 feet in twelve weeks ; while at Kew, Bambusa vul. garis is recorded as growing in favourable seasons at the rate of eighteen inches per day; and at Chatsworth the same species has attained the height of 40 feet in forty days. For the purpose of paper-making the stems should be cut down in a comparatively young state, before they become too woody, and reduced to pulp or half stuff before being sent to this country.

\section{SCIENTIFIC SERIALS}

American Foumal of Science and Arts, October.-This number contains the following two papers read at the Detroit meeting of the American Association for the Advancement of Science. -Address of Dr. John Le Conte, the retiring president.--A comparison between the Ohio and West Virginia sides of the Alleghany coal-field, by E. B. Andrews.-There is also a reprint from the Philosophical Magazine of Mr. Mallet's paper on the temperature attainable by rock-crushing. - In an obituary notice of Sir Charles Lyell, there is introduced an extract of a letter from Dr. Mantell to Prof. Silliman, in 1841 , describing bow Mantell and Lyell frst net.- The original articles in this number are: On the arithmetical relaticns between the atomic weights, by M. D. C. Hodges. - A note by L. F. Pourtales recording the corals found at the Galapagos Islands.-On instinct (?) in hermit crabs, by Alexander Agıssiz. This records bow young crabs reared without shells during their growth, "made a rush" for them as soon as they were placed in the tank where they were living.--On Southern New England during the melting of the great glacier, Part ii. We reserve our notice of this till the paper is completed.

Geological Magazine, October.-The original articles are: The Geology of Central Sumatra, by R. D. M. Verbeek (superintendent of the Geological Survey of Sumatra). This is stated to be the commencement of a series of articles on the subject, published with the authority and assistance of the DutchIndian Government. The oldest rocks in this part of Sumatra are granites, granite-syenites, and syenites. Then follow sedimentary rocks classed as of Carboniferous or Permian age. "This oldest sedimentary formation of Sumatra can be divided into two parts. The lower portion consists of clay-slates with atriferous quartz-veins, marl-slates and siliceous schists; the upper part consists only of limestone, with some small beds of schists." There are quartz porphyries and greenstones, the age of which is not known, but they are probably older than the tertiaries. The tertiaries themselves are divisible into five groups. The trachytic rocks are younger than the tertiaries. Three clearly drawn sections illustrate the paper, and a list of principal papers on the geology of Sumatra is given.--On the origin of Coums, by'J. G. Goodchild. That many of these cauldron-like hollows are due to the eddying of ice is the argument of $\mathrm{Mr}$. Goodchild.-Dr. Walter Flight continues his "History of Meteorites."-Dr. Thomas Wright records the occurrence of the genus Cotylederma in the middle lias of Dorsetshire.

Poggendorff's Annalent, No. 8.-This number commences with an investigation by Karl Müller as to the pitch of the transversal vibrations of bars of gypsum, when these are saturated with different droppable liquids. It appears that the liquid does not act as a weighting of the bar, but enters into union with the molecules of the substance, diminishing the co-efficient of elasticity; and this is manifested in a fall of pitch, the fall having 